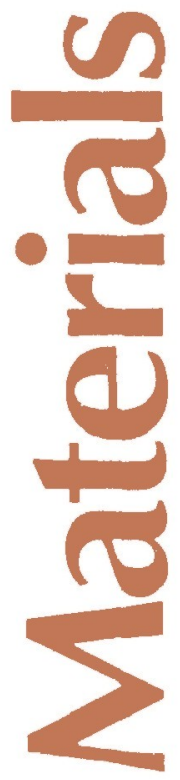

\title{
DOCUMENT HIGHLIGHTS:
}

Asian-African Legal Consultative Committee Bilateral Models for Judicial Assistance China-Japan Tax Agreement Iran-United States Claims Tribunal Final Award in American International Group Expropriation

US Federal Trade Commission Action on Toyota-General Motors Joint Venture US Withdrawal from UNESCO

VOLUME XXIII

NUMBER 1

JANUARY 1984

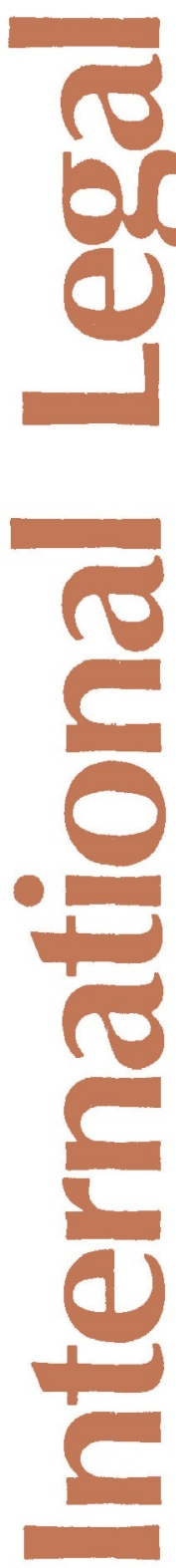


INTERNATIONAL LEGAL MATERIALS

Table of Contents

Volume XXIII

1984

\section{JUDICIAL AND SIMILAR PROCEEDINGS}

CANADA: Supreme Court Judgment concerning Juris-

diction over the Seabed and Subsoil of the

continental Shelf off Newfoundland, March 8, 1984. . . . . 23:288

Mar 84

EUROPEAN COMMUNITIES: Commission Decision concerning

a Proceeding under Article 85 of the EEC Treaty

(Restrictive Business Practices: International

Energy Agency Emergency Qil Sharing System),

December 12, 1983... . . . . . . . . . . . . . . . . 23:457 MaY 84

FRANCE :

Court of Appeals of Paris Decision in Arab Republic of Egypt $v$. Southern Pacific Properties

Ltd. et al. (Appellate Review of Arbitral Awards

between States and Private Parties) July 12, 1984 . . . 23:1048

Court of Cassation Decision in EURODIF Corporation

et all. $y$. Islamic Republic of Iran et al.

(Immunity from Execution: Attachment of Property: Commercial Transactions), March 14, 1984...... . . 23:1062

INTER-AMERICAN COURT OF HUMAN RIGHTS: Advisory Opinion

with regard to Questions relating to the Interpretation

of Provisions in the American convention on Human Rights

concerning the Death Penalty, September 8, 1983.... . . . 23:320

INTERNATIONAL CENTRE FOR THE SETTLEMENT OF INVESTMENT

DISPUTES ARBITRAL TRIBUNAL: Award on Jurisdiction in

the Matter of the Arbitration between Amco Asia Corpo-

ration et al. and Indonesia, September 25, 1983... . . . 23:351

INTERNATIONAL CHAMBER OF COMMERCE COURT OF ARBITRATION:

Interim Award Regarding Jurisdiction in the Arbitration

between westland Helicopters Ltd. and the Arab Organi-

zation for Industrialization, United Arab Emirates, Saudi

Arabia, Qatar, Egypt, Arab British Helicopter Company,

March 5, 1984... . . . . . . . .......... . . . 23:1071

INTERNATIONAL COURT OF JUSTICE:

Case concerning Delimitation of the Maritime Boundary

in the Gulf of Maine Area (Canada/United States)

Judgment, October 12, 1984. . . . . . . . . . 23:1197

Technical Report, October 3, 1984. . . . . . . . . . 23:1248

Separate Opinion of Judge Schwebel,

October 12, 1984 . . . . . . . . . . . . 23:1251

Dissenting Opinion of Judge Gros, October 12, 1984 . . . . . . . . . . . . 23:1254

Charts Mentioned in Paragraph 242. . . . . . . . . 23:1270

Case concerning Military and Paramilitary Activities

in and against Nicaragua (Nicaragua $y$. United States)

Order with regard to Request for the Indication of

Provisional Measures, May 10, 1984...... . . . 23:468

May 84

Order Fixing Time-Limits for Written Proceedings

on Questions of Jurisdiction and Admissibility,

May 14, 1984.................... 23:488

Sep 84

Nov 84

Nov 84

Nov 84

Nov 84

Nov 84

IRAN-UNITED STATES CLAIMS TRIBUNAL:

Case concerning Starrett Housing Corporation, et al.

and the Government of the Islamic Republic of Iran,

et al. (Expropriation of Property: Appointment of

Expert to Determine Amount of Compensation: Expert's

Terms of Reference)

Interlocutory Award, December 19, 1983 . . . . . 23:1090

Sep 84

Concurring Opinion, December 20, 1983. . . . . . . 23:1120

Sep 84 
JUDICIAL AND SIMILAR PROCEEDINGS (cont.) IRAN-UNITED STATES CLAIMS TRIBUNAL (cont.)

Case concerning the American International Group, Inc./American Life Insurance Company and the Islamic Republic of Iran/Central Insurance of Iran (Nationalization of Iranian Insurance Company: Compensation for Equity Interest Held by American Corporation and Wholly-Owned Subsidiaries of American Corporation)

The Award, December 19, 1983 .. . . . . . . 23:1 Jan 84 Concurring Opinion, December 30, 1983....... 23:14 Jan 84

Decision in Case No. A/18 concerning the Question of Jurisdiction over claims of Rersons with Dual

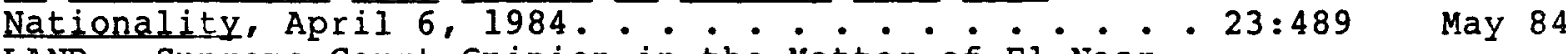
SWITZERLAND: Supreme Court Opinion in the Matter of El Nasr Export Import \& Co. $\mathrm{V}$. Anglo French Steel Corporation S.A. (Jurisdiction of Arbitration Tribunal; Application for Stay of Arbitral Proceedings), February 18, 1983 ........ 23:1143 Sep 84 UNITED KINGDOM:

High Court of Justice (Queen's Bench Division) Judgment concerning Judicial Assistance in the Santa Fe Case, February 23, 1984.. . . . . . . . . . . . 23:511 May 84

House of Lords Judgment in Alcom Limited $\forall$. Colombia, et al. (Commercial Liabilities; Sovereign Immunity: Attachment of Embassy's Bank Account), April 12, 1984.... . . . . * . . . . . . 23:719 Jul 84

House of Lords Judgment in British Airways Board $\underline{ }$. Laker Airways Ltd. (U.S. Jurisdiction in Antitrust Action: British Protection of Trading Interests Order), July 19, 1984 ...............23:727 Jul 84 UNITED STATES:

Court of Appeals for the District of Columbia Circuit: Decision in Ramirez $y$. Weinberger (Executive Power to Take Private Property: Executive Authority to Conduct Military Exercises on Land in Honduras Owned by U.S. Citizen: Nonjusticiable Political ouestions; Act of State Doctrine), October 5, 1984 . . . . . . . . . 23:1274 Opinion in Rehearing of Persinger v. Iran (Eoreign Sovereign Immunities Act: Jurisdiction over Activities at U.S. Embassies), March 13, 1984 . . 23:384

Court of Appeals for the Second Circuit Decision in Allied Bank $y$. Banco Credito Agricola de Cartago, et al. (Act of State Doctrine; External Debt Renegotiation: Payment Default on Promissory Notes), April 23, 1984.... . . . . . . . . . . . . . 23:742

Court of Appeals for the Sixth Circuit Decision in Ralamazoo Spice Extraction Co. y. The Provisional Military Government of Socialist Ethiopia (Act of State Doctrine; Adjudication of Expropriation Claim: Legal Standard for Compensation in Bilateral Treaty), March 9, 1984............... 23:393

District Court for the District of Columbia Opinion in Laker Airways Ltd. $y$. Pan American World Airways, et al. (Hague Convention on Taking Evidence Abroad in Civil or commercial Matters; Obtaining Evidence through U.S. Procedures), June 26, 1984...... . 23:748 istrict Court for the Northern District of Alabama (Eastern Division) Memorandum of Opinion Setting As ide Default Judgment in Jackson $Y$. People's Republic of China (Foreign Sovereign Immunities Act: Service of Process: U.S.-Sino Relations), February 27, 1984.................. 23:402 
JUDICIAL AND SIMILAR PROCEEDINGS (cont.) UNITED STATES (cont.)

District Court for the Northern District of Illinois (Eastern Division) Memorandum Opinion and Order in Graco $y$. Rremlin, Inc. (Hague Convention on Taking Evidence abroad in Civil or Commercial Matters: Erench Blocking Statute: obtaining Evidence through U.S. Procedures), April 13, 1984 . . 23:757 Jul 84

District Court for the Southern District of New York in Banque Compafina $\underline{v}$. Banco de Guatemala, et al. (Prejudgment Attachment of Central Bank's Assets: Foreign Sovereign Immunities Act: Waiver of

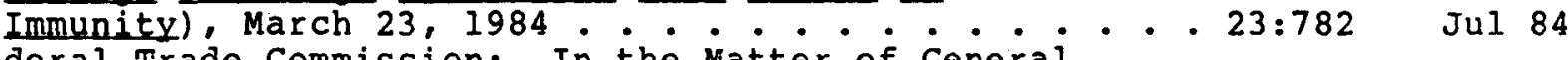

Federal Trade Commission: In the Matter of General Motors Corporation and Toyota Motor Corporation (Japanese-United States Joint Venture: Anticompetitive concerns)

Agreement Containing the Consent Order, December 22, 1983.................. 23:24

Appendix Containing the Complaint and the Toyota-General Motors Memorandum of Understanding, December 22,1983 and February 17 , 1983 respectively. . . . . . . . . . . . . 23:32

Commission Statements concerning the Proposed

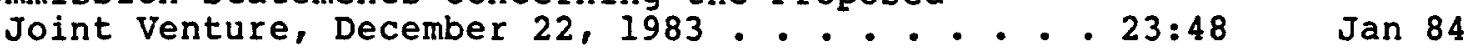

Dissenting statements concerning the Proposed Joint Venture, December 22, 1983. . . . . . . . 23:56 Jan 84

Judicial Proceedings in Antitrust Action of Laker

Airways Limited (Jurisdiction in Antitrust Action:

British Injunctions)

Introductory Note. . . . . . . . . . . . 23:517

Summary of Amicus Report, February 28, 1984. . . . 23:598

May 84

U.K. Court of Appeal (Civil Division) Judgment Granting British Airways Board and British Caledonian Airways Injunctive Relief, July 26,1983 . Court of Appeals Decision in Laker Airways $y$. Sabena and KLM, March 6, 19....... . 23:519

U.S. District Court for the District of Columbia Memorandum Reviewing Proceedings and Appointing Amicus curiae to Assist Court,

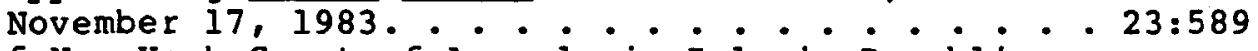

state of New York Court of Appeals in Islamic Republic

of Iran v. Pahlavi (Forum Non Conveniens: Powers

of the Executive), July 5, 1984. . . . . . . . . . . 23:1150 Supreme Court:

Opinion in Regan v. Wald (Treasury Regulations preventing Travel to Cuba: Trading with the Enemy Act), June 28, 1984... ...... . 23:792

Opinion in Trans World Airlines $y$. Franklin Mint (Liability Iimits under Warsaw Convention: Enforceability of Convention in U.S. courts: Use of Last official Price of Gold to Determine Limits in U.S. Dollars). April 17, 1984................... 23:814

U.S. Brief Submitted in Response to Court's Invitation in Club Mediterranee $v$. Dorin (State court orders for Interrogatories ve utilization of Hague Evidence Convention).

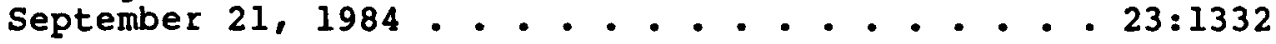

May 84

May 84

May 84

Sep 84

Jul 84 
JUDICIAL AND SIMILAR PROCEEDINGS (cont.) UNITED STATES (cont.)

Supreme Court (cont.)

U.S. Brief Submitted in Response to the Court's Invitation in Volkswagenwerk Aktiengesellschaft

v. Falzon (State Court orders for Depositions

in Federal Republic of Germany: Hague Convention

on the Taking of Evidence: Bilateral Exchange of Notes on the Taking of Eyidence),

November $7,1983 . . . . . . . . . . . . . .23: 412$

Mar 84

TREATIES AND AGREEMENTS

AMERICAN ARBITRATION ASSOCIATION-HUNGARIAN CHAMBER

OF COMMERCE: Memorandum of Agreement concerning

the Optional Arbitration Clause for Use in Contracts

in US-Hungarian Trade, September 7, 1984 . . . . . . . . 23:1342 Nov 84

ANGOLA-BURUNDI-CAMEROON-CENTRAL AFRICAN REPUBLIC-CHAD-

CONGO-EQUATORIAL GUINEA-GABON-RWANDA-SAO TOME AND

PRINCIPE ZAIRE: Treaty for the Establishment of the

Economic Community of Central African States,

done October 19, 1983. . . . . . . . . . . .

AUSTRALIA-BOLIVIA-INDONESIA-MALAYSIA-NIGERIA-THAILAND-

ZAIRE: Special Meeting to Adopt the Agreement for

the Association of Tin Producing Countries, done

March 29, 1983; entered into force september 29, 1983. . . 23:1009

ASIAN-AFRICAN CONSULTATIVE COMMITTEE:

Introductory Note, May 1983 ........... 23:78

Jan 84

Model Bilateral Arrangements:

Mutual Assistance for the Service of Process and

the Taking of Evidence Abroad in Civil or

Commercial Matters, May 1983... . . . .. 23:83

Jan 84

Mutual Assistance on Letters Rogatory in Criminal

Matters, May 1983...............23:103

Jan 84

Promotion and Protection of Investments,

January $\frac{\text { and }}{30}$ - Febrotection of Investments, 1 . . . . 23:237 Mar 84

BELGIUM-FRANCE-FEDERAL REPUBLIC OF GERMANY-ITALY-JAPAN-

NETHERLANDS-UNITED KINGDOM-UNITED STATES : Provisional

Understanding regarding Deep Seabed Mining

Provisional Understanding, August 3,1984 ...... . 23:1354

Memorandum of Implementation, August 3, 1984. . . . . 23:1358

Exchange of Diplomatic Notes, August 3, 1984... . . 23:1361

FRG Declaration on Berlin, August 3, 1984 . . . . . . 23:1363

Declarations in Accordance with Paragraph 12,

August 3,1984.................. 23:1364

Agreed Minute to Agreement concerning Interim

Arrangements relating to Polymetaliic Nodules of

the Deep Seabed, August 3,1984........... 23:1365

Sep 84

Sep 84

Jan 84

Nov 84

Nov 84

Nov 84

Nov 84

Nov 84

Nov 84

BULGARIA-CZECHOSLAVARIA-GERMAN DEMOCRATIC REPUBLIC-HUNGARY-

MONGOLIA-POLAND-UNION OF SOVIET SOCIALIST REPUBLICS:

Agreement on the Establishment of the International

Investment Bank and Statutes of Bank, done

July 10, 1970; entered into force February 5,

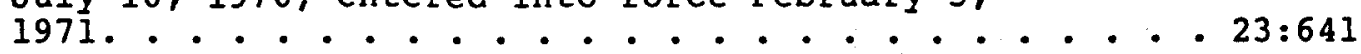

Agreement concerning Multilateral Settlements in

Transferable Rubles and the Organization of the

International Bank for Economic cooperation and

Statutes of the Bank, done October 22, 1963;

entered into force May 18, 1964.......... 23:650

May 84

CANADA-DENMARK: Agreement for Cooperation relating

to the Marine Environment, done and entered into

force August 26, 1983... . . . . . . . . . . . . 23:269

Mar 84 
TREATIES AND AGREEMENTS (cont.)

CANADA-UNITED STATES: Memorandum of Understanding as

to Notification. Consultation and Cooperation with

respect to the Application of National Antitrust Laws,

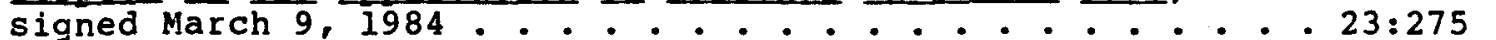

PEOPLE'S REPUBLIC OF CHINA-JAPAN: Agreement for the

Avoidance of Doukle Taxation and the Prevention of

Eiscal Evasion with Respect to Taxes on Income,

done september 6,1983 .................. . . 23:120

PEOPLE'S REPUBLIC OF CHINA-UNITED RINGDOM: Agreement on

the Euture of Hong Bong, initialed September 26, 1984. . . 23:1366 Nov 84

PEOPLE'S REPUBLIC OF CHINA-UNITED STATES:

Accord on Industrial and Technological Cooperation,

done and entered into force January 12, 1984. . . . . 23:144 Jan 84

Agreement for the Aveidance of Double Taxation and the Rrevention of Tax Evasion on Income, done April 30, 1984................ . 23:677

Jul 84

HAGUE CONFERENCE ON PRIVATE INTERNATIONAL LAW: Final ACt

Introductory Note .................... 23:1388

Nov 84

Convention on the Law Applicable to Trusts and on Their Recognition, October 20, 1984........ 23:1389

Decisions on the Agenda of the Conference, October 20, 1984................... 23:1392

INTERNATIONAL CIVIL AVIATION ORGANIZATION: Amendment of

International Civil Aviation Convention with regard to

Interception of civil Aircraft, May 10, 1984.... . . . 23:705

INTERNATIONAL MARITIME ORGANIZATION:

Convening of an International Conference on Liability

and Compensation for Damage in Connection with

the Carriage of Certain Substances by Sea,

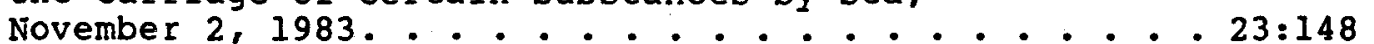

Draft Convention on Liability and Compensation in

Connexion with the Carriage of Noxious and

Hazardous Substances by Sea, January 13, 1984 . . . . 23:150

Draft Protocol to the International Convention on Civil Liability for oil Pollution Damage,

1969, November 2, 1983..................... 23:177

Nov 84

Nov 84

Draft Protocol to the International Convention

on the Establishment of an International Fund

Eor Compensation for oil Pollution Damage,

1971, November 2, 1983. . . . . . . . . . . . 23:195

LIBYA-MOROCCO: Treaty Instituting the Arab-African

Union of States, done August 13, 1984; entered into

force September 1, 1984... . . . . . . . . . . . . 23:1022

MOZAMBIQUE-SOUTH AFRICA: Agreement on Non-Aggression

and Good Neighbourliness, done March 16, 1984....... 23:282

Jul 84

PANAMA-UNITED KINGDOM: Agreement for the Promotion

and protection of Investments, done October 7, 1983. . . . 23:708

SOUTH AFRICA-SWAZILAND: Agreement concerning Security,

entered into force February 17, 1982 . . . . . . . . . 23:286

UNION OF SOVIET SOCIALIST REPUBLICS-UNITED STATES:

Memorandum of Understanding on the Direct Communications

Link, July 17, 1984.................... . 23:1393

UNION OF SOVIET SOCIALIST REPUBLICS-VIET NAM: Agreement

on Long-Term Program for the Development of Economic,

Scientific and Technical cooperation, done

October 31, 1983 .... . . . . . . . . . . . . . . . 23:659

UNITED NATIONS: Draft Convention against Torture and

other cruele Inhuman or Degrading Treatment or

Punishment, March 9, 1984................. 23:1027

Jan 84

$\operatorname{Jan} 84$

Jan 84

Jan 84

Sep 84

Mar 84

Jul 84

Mar 84

Nov 84

May 84

Sep 84 
LEGISLATION AND REGULATIONS

ANDEAN GROUP: Commission Decision on the statute of

the court of Justice of the cartagena Agreement

Introductory Note ....................... . 23:422 Mar 84

Decision 184, adopted August 18-19, 1983. . . . . . . . . 23:425 Mar 84

AUSTRALIA:

Eoreign Rroceedings (Excess of Jurisdiction)

Act 1984, March 2I, 1984.............. 23:1038

Summary of Recommendations and Draft Legislation

on Eoreign State Immunity, July, 1984. . . . . . . . . 23:1398 Nov 84

BULGARIA: Amendments to the Regulation Implementing the

Law on Passports

Introductory Note . . . . . . . . . . . . . . . . . 23:442

Mar 84

Text of Amendments, June $28,1983$. . $_{1}$. . $_{1}$. . . . . . . 23:445 Mar 84

EUROPEAN COMMUNTIES: Council Regulation strengthening

the common Commercial Policy to Protect against Illicit

commercial practices of Third countries and conseguent

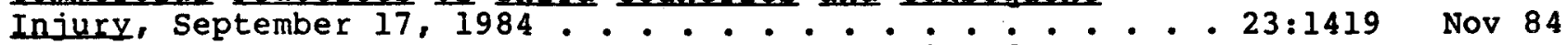

SWITZERLAND: Excerpt on International Arbitration from

the Draft Statute on Frivate International Law,

November 10, 1982. . . . . . . . . . . . . . . . 23:713

UNION OF SOVIET SOCIALIST REPUBLICS:

Rules for the Sojourn ef Eoreign citizens,

July 1, 1984..................... . 23:1425

Rules for the Transit Passage of Foreign Citizens

Across the Territory of USSR, July I, 1984. . . . . 23:1432

Jul 84

Nov 84

Nov 84

\section{REPORTS}

INTERNATIONAL CIVIL AVIATION ORGANIZATION: Action with

Begard to the Downing of the Borean Air Lines Aircraft

Council Resolution and Report of ICAO Fact-Finding

Investigation, December 1983............ 23:864

Air Navigation Commission Technical Review of

the Fact-Finding Investigation and Council

Resolution Condemning the Destruction of the

Aircraft, January 24 to February 16,1984

and March 6, 1984................. 23:924

Jul 84

THE CONTADORA RROCESS FOR PEACE IN CENTRAL AMERICA:

Cancun Declaration on Peace in Central America,

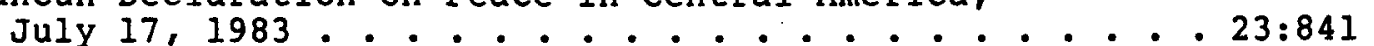

Jul 84

Communique of the Contadora Group and Central

American Countries on Measures to Implement

Their Objectives, January 8, 1984......... . 23:857

Costa Rica-Nicaragua Joint Declaration, May 15, 1984. . 23:863

Information Bulletin on the Contadora Group,

May 12, 1983..................... 23:836

Information Bulletin on Joint Meeting of Contadora

Group and Central American Countries,

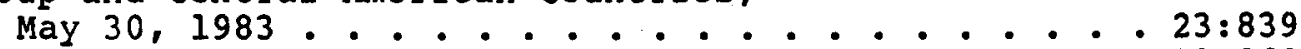

May 1, 1984.................. . . 23:860

U.N. General Assembly Resolution, November 11, 1983 . . 23:849

U.N. Secretary-General's Note including the Contadora

and Central American Document of Objective,

October 13, 1983, reissued October 18, 1983..... . 23:844

JuI 84

U.N. Secretary-General's Note including the Contadora

Group's Communication to the O.A.S. and the O.A.S.

Resolution, December 9, 1983 and November 18, 1983. . 23:852

U.N. Security Council Resolution, May 19, 1983. . . . . 23:838

Jul 84

Jul 84

Jul 84

Jul 84

Jul 84

Jul 84

Jul 84

JuI 84

Jul 84

UNITED NATIONS COMMISSION ON TRANSNATIONAL CORPORATIONS:

Draft U.N. Code of Conduct on Transnational Corporations,

March 7-18 and May 9-21, 1983........... 23:626

May 84 
REPORTS (cont.)

UNITED NATIONS COMMISSION ON TRANSNATIONAL CORPORATIONS (cont.)

Report of the Secretariat on the Qutstanding Issues in the Draft Code of Conduct on Transnational Corporations, May 29, 1984............. 23:602

OTHER DOCUMENTS

ARGENTINA-BOLIVIA-BRAZIL-CHILE-COLOMBIA-DOMINICAN REPUBLIC-ECUADOR-MEXICO-PERU-URUGUAY-VENEZUELA:

Cartagena Communique on Foreign Debt and Economic

Development, June 22, 1984 ... . . . . . . . . . . 23:1169

AUSTRIA-CANADA-DENMARK-F INLAND-FRANCE-F EDERAL REPUBLIC

OF GERMANY-NETHERLANDS-NORWAY-SWEDEN-SWITZERLAIND:

Declaration on Acid Rain, March 21, 1984 . . . . . . . . 23:662

CANADA-EUROPEAN COMMUNITIES-FRANCE-FEDERAL REPUBLIC OF

GERMANY-ITALY-JAPAN-UNITED KINGDOM-UNITED STATES:

London Communique on the Resolution of Debt Problems,

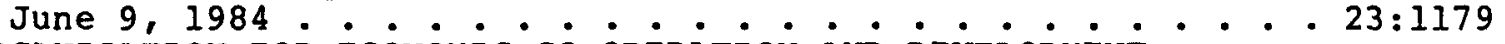

ORGANISATION FOR ECONOMIC CO-OPERATION AND DEVELOPMENT:

Council Decision and Recommendation on Transfrontier

Movements of Hazardous Waste, February 1, 1984. . . . 23:214

Council Recommendation concerning Information Exchange

related to the Export of Banned or Severely

Restricted Chemicals, April 4, 1984 . . . . . . . . 23:664

SOUTH AFRICA: Statement concerning the Lusaka Agreement

Formalizing a Ceasefire on the Border between angola

and Namibia, February 16, 1984.............. 23:450 UNITED NATIONS:

General Assembly Resolution on New International Human Order = Moral Aspects of Development and the ECOSOC

Draft Declaration, December 19, 1983......... . 23:938

Security Council Draft Resolution Condemning the Mining

of Nicaraguan Ports, April 4, 1984.......... 23:669

UNITED STATES:

Letter to the U.N. Secretary-General concerning Non-

Applicability of Compulsory Jurisdiction of the International court of Justice with regard to Disputes with Central American States, Aprii 6, 1984 . . . . 23:670

Memorandum on the Application of International Law to Iranian Eoreign Exchange Regulations, February 15, 1984. . . . . . ................. 23:1182

Withdrawal from UNESCo:

U.S. Message to the Secretary-General of the U.N., December 29,1983 . . . . . . . . . . . . 23:218

U.S. Letter to the Director-General of UNESCO, December 28, 1983................ 23:220

UNESCO Letter in Response, January 18, 1984.... 23:224

Sep 84

May 84

Sep 84

$\operatorname{Jan} 84$

May 84

Mar 84

Jul 84

May 84

RECENT ACTIONS REGARDING TREATIES TO WHICH THE UNITED STATES

IS A PARTY ......................... . 23:231

$23: 451$

$23: 671$

$23: 941$

$23: 1190$

$23: 1436$

May 84

Sep 84

Jan 84

Jan 84

Jan 84

Jan 84

Mar 84

May 84

Jul 84

Sep 84

Nov 84

RECENT ACTIONS REGARDING TREATIES TO WHICH THE UNITED STATES

IS NOT A PARTY ...................... 23:235 
INDEX TO VOLUME XXIII . . . . . . . . . . . . . . . . . . 23:1445



